\title{
The Growth of Higher Educators for Social Justice: Collaborative Professional Development in Higher Education
}

\author{
Molly K. Ness, PhD \\ Assistant Professor, Childhood Education \\ Fordham University \\ Marshall A. George, PhD \\ Associate Professor, English Education \\ Fordham University \\ Kristen Hawley Turner, PhD \\ Assistant Professor, English Education \\ Fordham University \\ Jane Bolgatz, PhD \\ Associate Professor, Social Studies Education \\ Fordham University
}

In this article, we investigate what happened when, contrary to the typical isolation of faculty in higher education, a group of higher educators from various disciplines in a graduate school of education met regularly to discuss issues related to our teaching and social justice. More specifically, we explored the following research question: How does collaboration among higher educators from various disciplines shape their beliefs and practices of teaching for social justice? Over three years of collaboration and conversation, not only did we expand our own knowledge and understandings of notions of social justice, but we began to take important steps towards increasing our social justice actions in our teaching. This article explores our efforts to create a self-directed professional development group of higher educators and provides suggestions for similarly interested higher educators.

Professional development in higher education is often lonely work. Sitting in seminars, reading scholarly journals, or preparing conference presentations happens most frequently in isolation. Though some might argue that each of these acts is dialogic, often they involve little collaboration, are intermittent, and sometimes are motivated by extrinsic factors (promotion and tenure). In contrast, research shows that the most effective forms of professional development are voluntary, ongoing, and collaborative (Brancato, 2003; Cochran-Smith \& Lytle, 1999; Rogers et al., 2005; Smith, 2003). In this article, we investigate what happened when, contrary to the typical isolation of faculty in higher education, a group of higher educators from various disciplines in a graduate school of education met regularly to discuss issues of social justice related to our teaching. Brought together by our department chair who opened a forum for faculty to share research interests, our group was comprised of six to nine higher educators. The result of three years of collaboration was a journey of professional development, with rich opportunities to explore issues of social justice in teacher education. We first delineate our assumptions about adult learning and our understandings about social justice that frame the study of our three-year collaboration. We then describe our group's methodology and the process and outcomes of our work. 


\section{Adult Learning and Collaboration}

For much of the last century, researchers who examined the professional lives of teachers consistently found that teachers work in isolation, in the insulated environment of their own classrooms (Little, 1990; Lortie, 1975). However, efforts have been made at all levels of education to break down the barriers of solitude facing teachers and to create "professional communities of teachers" (Grossman, Wineburg, \& Woolworth, 2001). Scholarly literature from the field of education increasingly describes teacher inquiry groups (Chandler-Olcott, 2002; CochranSmith \& Lytle, 2001; Fecho \& Allen, 2003), educator networks (El-Haj, 2004), collaborative study groups (Lewis \& Ketter, 2004; Lyons \& Pinnell, 2001), and faculty learning communities (Richlin \& Cox, 2004). While such professional development efforts are more common in primary and secondary school settings, the twenty-first century has seen increasing attention paid to higher education faculty involved in collaborative professional development endeavors (Brancato, 2003; Fecho, 2000; Richlin \& Essington, 2004; Rogers et al., 2005; Sandretto et al., 2007).

Understandings of ourselves as adult learners guided our collaborative efforts. Specifically, we operated with two assumptions about adult learners: 1) that we, as adult learners, are motivated to learn when learning is relevant and meaningful to us (Pratt, 1998; Wlodkowski, 1999), and 2) perspective transformation can occur when we, as adult learners, engage in our own reflectionon-action (Moon, 1999; Schon, 1997) and dialogue with others (Brookfield, 1987; Mezirow, 2000).

West (1996), when discussing group learning experiences in the workplace, suggests that dialogue is the key to effective collaborative inquiry:

[Dialogue] allows for transforming the thinking that lies behind the words that are said.... The goal of dialogue is to help the group bring assumptions to the surface and clarify theories-in-use, which must happen before a shared set of meanings and a common thinking process can be developed. (p. 56)

Dialogue, however, needs to be more than sporadic conversations in the hallways or a one-day retreat at the beginning of the school year. Rather, ongoing efforts at communication are crucial to the success of professional development efforts. Rogers et al. (2005) suggest that "It is generally accepted that the most effective professional development occurs over time rather than in isolated moments" ( $p .348$ ). Dialogue and extended collaboration were at the heart of the process of our study group.

\section{Social Justice in Teacher Education: A Goal, a Process, and a Stance}

As faculty at a Jesuit university, we often see and hear the motto "men and women for others"-on flyers advertising community service projects, in graduation speeches, and in the university's promotional literature. It makes sense, then, that after beginning as a group to support one another's research, we quickly identified the topic of social justice as a common, if not yet defined, thread of our interest as higher educators. We began our work together with the belief that social justice was undeniably linked to our responsibilities of preparing K-12 teachers.

Our understanding of social justice evolved during the three years of our discussions. In our reflection on this process, we are guided by the understanding that social justice is simultaneously a goal, a process, and a stance (Grant \& Agosto, 2008). As a goal, social justice denotes equality of opportunities and outcomes for all people. It may be also be viewed as the process of confronting and dismantling oppressive structures and systems, the process of addressing inequalities of all 
kinds, and the process of developing recognition of and respect for the values and identities of all cultural groups. Finally, taking a social justice stance means embracing the need for change and reflecting on one's actions and questioning "commonsense" assumptions about the way things are. The stance is a lens through which one questions the world.

The construct of social justice is complex, and ours is not the first group of educators to tackle its meaning. Rogers et al. (2005) described the stages of a fouryear research group examining the complex relationships between professional development and social transformation. Cochran-Smith et al. (1999) demonstrated a "proof of possibility" to other teacher education faculty as they engaged in a "Seeking Social Justice" project at Boston College. Their nine-member multi-year collaborative research and professional development project encouraged faculty "to examine their own understandings of social justice issues as part of the process of helping their students do the same." They also sought to "encourage students to work for social

Taking a social justice stance means embracing the need for change and reflecting on one's actions and questioning "commonsense" assumptions about the way things are.

change and effectively meet the needs of the increasingly diverse K-12 school population" (p. 229). These authors suggest that the establishment of inquiry communities of "co-learners and co-researchers" (p. 233) might best facilitate the difficult work of placing social justice at the core of teacher education. The work of the Boston College faculty inspired our own "self-study" at both the departmental and individual faculty levels, as we explored our understandings of the construct of social justice as a goal, process, and stance.

\section{Guiding Questions}

As a community of "co-learners and co-researchers" (Cochran-Smith et al., 1999), we began with five broad questions about social justice:

1. How do teacher educators from various disciplines define social justice?

2. How do teacher educators from various disciplines explore issues of social justice with teacher candidates in their courses?

3. What happens when teacher educators from various disciplines explore social justice collaboratively?

4. How does collaboration among teacher educators from various disciplines shape their understandings and visions of integrating social justice into teacher education coursework?

5. How can our collaboration impact our graduate students and how, in turn, can or does this work impact our graduate students' K-12 students?

While we were all anxious to get to the last question-our ultimate goal was to impact the learning and lives of K-12 students, particularly those living in poverty in the large city where we taught-we decided to focus first on our own development as educators.

The following is an account of the work that we did to answer the first four questions. We first provide an overview of the three years; we then highlight four specific activities we engaged in recursively during our exploration of social justice in our teaching. Finally, we reflect on the impact that our professional development had on our teaching and offer suggestions for others who might want to engage in similar efforts. 


\section{Our "Teacher-Educators-for-Social-Justice" Inquiry Group}

Our learning community met from fall 2006 to spring 2009 at a Jesuit university in a major metropolitan area in the northeastern United States. Over the three- year collaboration, faculty members floated in and out of the group, but four core members remained voluntary participants throughout the inquiry. All of the participants had been elementary or secondary school teachers prior to working in higher education. Our areas of expertise were childhood literacy, middle school English education, secondary English education, social studies education, Teaching English to Speakers of Other Languages (TESOL), and adult education. At the start of the project, four members were in their first years of a tenure-track position, one member was in her sixth year, while the remaining member was a tenured, midcareer professor. The group was relatively homogenous in terms of class and race: most of us came from middle or upper-middle class backgrounds; one participant is Latina and the rest are white.

Members came to the group with differing intentions and interests. For example, as a junior faculty member, Molly joined in hopes of finding support among colleagues for her personal research and writing. Also a junior faculty member, Kristen became involved in order to collaborate with colleagues in research endeavors. Jane was intrigued by the opportunity to conduct collaborative research, while Marshall, having returned from a yearlong leave of absence working in a public school, was eager to rejoin the research world of higher education and to support the new faculty members who were joining the department.

Though initially we envisioned the group as a place to advance our individual research goals, as our work evolved, we began to see the process of our collaboration to be just as important as the products of our individual scholarship. At our initial meeting, we discovered that we were each exploring some aspect of critical pedagogy, language, and discourse within our specializations and that we were independently grappling with integrating social justice into our teaching.

Despite our university's commitment to ideals of social justice, we were concerned

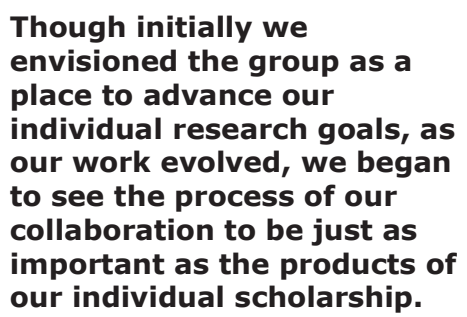

that our teacher candidates were not truly understanding or enacting social justice in their teaching. We decided, then, to broaden the focus of our group to serve both as support for our individual research efforts as well as a collaborative "teachereducators-for-social-justice" inquiry group (Cochran-Smith et al., 1999; CochranSmith and Lytle, 2001) around issues of social justice in our own practice. We agreed to meet monthly. We also agreed that we would collect and examine multiple sources of data so that we could better understand our professional development effort as well as its impact on our teaching.

\section{Year One: Our Journey Together Begins}

After initially agreeing to focus on our intersecting interest in social justice, we decided that it would be helpful to use texts to create a dialogic space (Nystrand, 1982) where we could explore others' views in order for "new, hybrid understandings and practices to emerge" (Anagnostopolous, Smith, \& Nystrand, 2008 , p. 4). Functioning as a faculty book club (George, 2004) or study group (Birchak et al., 1998) continued over the next two years, as we read and discussed a number of articles and book chapters that influenced the work we were doing as a 
study group collectively and as teacher educators individually (see Appendix A for reading list).

For our first text discussion, we read Courtney Cazden's (2001) Classroom Discourse: The Language of Teaching and Learning. We discussed the role of language in educational settings as well as the systematic methodologies that Cazden and others have used to study classroom discourse. At the conclusion of that meeting, we agreed that it was necessary to examine our teaching and the work we were doing individually to teach for social justice.

At the following meeting, we each brought artifacts to share to help us talk about the ways that we teach and students learn about social justice. The documents we shared included assignments from our syllabi and student work that resulted from those assignments. They included linguistic biographies, lists of works of adolescent literature used to explore social justice in book clubs, lists of reading assignments in adult education with a social justice focus, a cultural field trip assignment, cultural and linguistic case study of an urban community, and TESOL student reflections on their experiences in diverse classrooms. (See Appendices B and $C$ for examples; these artifacts served as the first data source for our self study.) Our examination of course assignments and the resulting student work confirmed Cochran-Smith et. al's (1999) suggestion that individuals construct social justice differently. Our discussion made it evident that group members did not operate with common, or even well-defined, understandings of the term social justice. This led us to two uncertainties that we felt the need to address: How do we, as a group and as individuals, define social justice? How can we be sure that our students are not merely parroting notions of social justice because they think they are supposed to?

\section{Our Efforts to Define Social Justice}

In an effort to capture our understandings of social justice, we decided to each write definitions of the term social justice and bring these to our "dialogic space" during the first meeting of the spring term. This marked our first use of the practice of professional development through writing (Diaz-Maggioli, 2004). It also marked the first formal philosophical steps that many of the group members had taken spurred by our inquiry.

At the meeting when we shared our definitions, the group engaged in spirited dialogues about each of them. In an audio-recorded session, we discussed points of connection and points of divergence among the definitions, and we were struck by the various ways group members interpreted the task to define social justice. Molly provided a strict textbook definition of social justice, explaining it as "the idea that society gives individuals and groups equal treatment, access, and share of benefits". Kristen, on the other hand, defined social justice by examining her own personal philosophy and her life narrative. She wrote that "social justice is about knowledge and action, empathy and support, and vision and effort. It is about people working together to create a better world, both socially and economically, for all who live in it." Marshall and Jane took more worldly views of the construct.

Marshall defined social justice as "a belief system, a process, and a goal that should drive education at all levels" and explained a social justice agenda as one that "challenges the inequalities that exist in our world today." Jane wrote that "a just society in which everyone enjoys equitable opportunities including being able to develop while being respected, honored, and having dignity." Finally, Aida approached the assignment by asking her graduate students for their understandings of the term, ultimately defining social justice as "both a theoretical and experiential construct.... which interrelates issues of inequality, lack of learning, and poor academic achievement." 
Ironically-given our concern about our students parroting definitionswhen we began to examine our own definitions, we were struck by their 'bookish' nature; in fact, several of us drew on outside sources to write our definitions. Kristen confessed that her definition was largely shaped by an online dictionary, and Marshall constructed his definition after reading relevant literature. Despite the personal nature of the task-to explain what social justice meant to us as individuals-several of us wrote very impersonal definitions. This sharing was important for our work, as it helped us realize that in order to effectively teach with social justice at the core of our programs, we needed to grapple with the construct, making it tangible to ourselves, before we could expect our students to do the same.

Like Cochran-Smith et al. (1999), we found common themes across our beliefs, including equity, access, empowerment, and respect. As the discussion turned back to our students, we argued that social justice involved "perspective transformation" of approaching others with humility and understanding, recognizing our own prejudices, taking ownership of bias, and seeing equity through a lens of diversity. Through our dialogue, as we searched for convergences and divergences across our

We found common themes across our beliefs, including equity, access, empowerment, and respect. individual definitions, we did not reach a consensus of what social justice is or how to actualize social justice. We realized, however, that our individual concepts of social justice influenced the differing processes by which we attempted to meet our goals of teaching for social justice (Grant \& Agosto, 2008).

Though we decided after that meeting that our study group should turn its focus to our pedagogy, our work in defining social justice and developing our individual philosophies was by no means complete. In subsequent weeks, we read the draft of a portion of the Handbook on Teacher Education ( $3^{\text {rd }}$ ed.) entitled "Teacher Capacity and Social J ustice in Teacher Education" (Grant \& Agosto, 2008) which gave us much insight into the issues we had grappled with during our conversations and served as the primary lens for the data analysis of our study group artifacts. We returned to our individual and collective definitions of social justice time and again over the three-year period and witnessed an evolution of our understanding of the term.

\section{Reassessing Old and Designing New Curricula}

At the final meeting of the first year of our collaboration, we again shared syllabi, assignments, and student work that highlighted issues of social justice in our teaching. Transcriptions of our audio-recorded session allowed us to examine what, if any, change had occurred in our teaching during the first year of our professional development efforts. We found that although our teaching, including reading and writing assignments, had changed little (most of us were teaching different courses in the spring than we had in the fall, making a comparison difficult), we all were aware that our understanding of, comfort with, and commitment to social justice had grown significantly in this short time. We also realized our students' work did not evidence any deep consideration of these issues

During that final spring meeting, Marshall, who had been reading graduation portfolios through the lens developed by his participation in the study group, shared the following reflection he had as he examined student work. One thing that I have become aware of in our programs is that I don't think that we necessarily do enough about the schoolcommunity connection, and how do you utilize the community resources. I've noticed [that my students] can all show that 
they've met the standards, but they are not doing it showing documents from [university] coursework. They are doing it [based on their experiences in the K-12 schools where they are student teaching], which is fine, but they don't have [our University] coursework.

Marshall's comment highlights an epiphany that many of us had during our conversation: if we wanted students to truly embrace teaching for social justice, we had to be more overt in our university-based courses.

In response to these conversations, five of the six group members developed and led a summer institute called With Literature and Justice for All. The institute was a two-week, intensive course with speakers from around the country sharing with our master's and doctoral students research and practice related to the integration of literacy development, literature study, and social justice. As we had during the previous two semesters, our students grappled with the meaning of "teaching for social justice." They created action plans for taking a social justice stance in their own classrooms and formulated the processes by which to do so. This event served as a capstone for our year as higher educators exploring social justice together and set us on the path of pedagogical transformation.

Though we realized success in pedagogical change via our inquiry group, the dialogic space served also as a place of resistance. During our sharing session, Molly expressed frustration with her inability to bring an assignment or student work to the table. The core course she was assigned to teach included required assignments, called "gateways." She reflected on this course with the group:

My class is all gateways, so I'm pretty constrained. And the gateway assignments are to create a thematic unit of instruction, a four-week unit about a social studies topic, or a science topic, or a chapter book or some major theme, and integrate literacy into that theme for the four weeks. And the second assignment is to teach and carry out some of that unit and reflect on the experience of planning it out and teaching it. So within those gateway assignments I have very little wiggle room as to what I can expect from them just because of the nature of the gateway. I think that there are social justice issues that are implied in both of the assignments as well as in my class. Certainly not anything as kind of deep or explicit and meaningful in some of the work that you guys have shared. They are expected to- Their unit is expected to reach all students and have specific instruction for the diverse needs of their learners, and they are expected to show evidence of that in their planning and how they went about differentiating their instruction to meet everyone's needs.... I have felt frustrated with gateways in general, and how gateways are evaluated.

The group could visibly see Molly's frustration about being unable to share work that she considered "meaningful" during our discussion. Initially, group members focused on responses that would help Molly uncover the "social justice issues that are implied" in her course, but Kristen turned the conversation, pushing Molly to rethink her approach to gateway assignments.

Kristen: I guess I'm just wondering, I mean the gateway assignments, at least the ones that I've been given, they are assignments, but the angle that you take on the assignments could vary. It has to be literacy across the content area, but could you require that they take a social justice slant on that?

Molly: I think I could, but I think that these gateways are a little more scripted. 
Kristen: Oh, okay.

Molly: And again, when I came I took [a colleague's] work and [my colleague] and I would probably approach the class in very different ways, and it's a challenge to take somebody else's syllabus and make it yours when you are very unfamiliar with the larger framework of the university. So that was my struggle with it the first semester.

Kristen: There's still a tension. I think we are all sitting here and seeing the tension in you.

Molly's experience reflected the tensions many of us felt as we explored issues of social justice; the inquiry group offered us a safe and collegial space to grapple with them.

\section{Year Two: Being More Overt}

Year two was somewhat different from the first. With two of the six members departing on leave for the fall 2007 semester, the group did not taperecord another formal meeting until spring 2008, though we continued discussions and collaborations via email, through informal conversations, and via our scheduled monthly meetings. Whereas social justice as goal and stance had been our focus during that first year, we spent year two working out individually how we could implement the processes of teacher education for social justice (Grant \& Agosto, 2008).

We came together in formal group meetings during the spring of year two to share our individual progress. Once again, we tape-recorded these discussions. We also prepared written reflections, focusing on how our notions of social justice had expanded through our conversations and other activities that had occurred over the previous year and a half; we focused, too, on how this inquiry process and collaborative work impacted our teaching, research, and professional development. Across these recordings and writings, it was evident that the conversations raised members' awareness of connecting social justice to their teaching, research, reading, and personal lives.

Nearly all members noted that they scrutinized and evaluated their course content, assignments, and readings because of their participation in the collaborative group. Kristen explained, "My text selection is currently influenced by our work in this research group, and the assignments I make are also subject to scrutiny. My classroom talk is more conscious." Marshall noted that notions of social justice "were emerging as one of the underlying themes of my teaching." Inspired by Kristen's Linguistics Dimensions Study (see Appendix B), Jane began designing assignments for her classes that required students to analyze dimensions of their students' communities in terms of strengths and challenges (see Appendix D). She had not had those assignments in the courses previously.

Aida's reflection summarized for us the path we had each taken as we evaluated student work and explored notions of social justice in our teaching:

Last year, as part of this research group I offered an initial definition of social justice based on a group of candidates comments about this topic. This survey that I did with students made me aware of the need to examine this issue more in depth in the courses that I teach. I guess that I was just assuming that because of the content of my courses, this issue of social justice was a given.

Overcoming this assumption- that our students would understand and actualize social justice because we believed it was important- was an important result of our collaboration. We could no longer allow social justice to lie in the background of our 
teaching; we had to be more overt. The literacy institute that focused on social justice marked our first step. Our ongoing informal and formal conversations provided the support each of us needed to continue our growth. A year after she articulated her struggle with attending to issues of social justice in a course that required particular assessments of her students, Molly wrote and then shared the following with the group:

In my Literacy Across the Curriculum courses, I've included more readings and discussions about culturally responsive teaching. Furthermore, because of these conversations, I've added a new element into the theme unit assignment. I now require students, in their reflective papers, to provide evidence for how they prove themselves to be culturally responsive teachers. Furthermore, social justice issues permeate my doctoral class in which we study applied linguistics and issues of power and culture that are inherent in language. This discussion is supported with readings by Purcell-Gates and Shirley Brice-Heath. This is the beginning of what [Brice-Heath] would prove to be a "fruitful personal transformation."

For Molly, prior to joining the group, "social justice was a buzzword, a platitude or an idea without significant substance." When she asked her students, she found that she was not alone. She said, "At the start of the summer institute, many of my students were unable to provide a definition for social justice. In the course of those two weeks, this dramatically changed with all students having something to say about social justice and how it pertains to their lives and to their teaching." This transformation-of Molly's teaching and of her students' understanding-mirrored the experience of many group members. After two years of conversation, reading, and writing, our group members were now much more overt in their teaching for social justice.

\section{Year Three: Understanding Our Progress and Continuing Onward}

In the third year, membership shifted as we invited new faculty to join us and others chose not to attend. During year three, we continued the faculty book club approach, reading common texts as a group and sharing other readings we had completed individually or in pairs. A few people read chapters from Diversity and the New Teacher: Learning from Experience in Urban Schools (Cornbleth, 2008). Others read selected chapters from White Teachers, Diverse Classrooms (Landsman \& Lewis, 2006) and the Grant and Agosto (2008) article. Finally, a couple of members (including a new group member) read excerpts of various works of Michael Foucault.

Our work also continued through informal conversations about what was happening in our classes. We regularly sent articles to each other and dialogued about them via email or at department meetings.

The conversations we had were a combination

\section{We recognized that our professional development efforts were recursive rather than linear in nature and that our recursive process had affected us as researchers and teachers.}

of theory building and practical questions. The study group had evolved from formal monthly meetings to a support network that transcended the walls of our individual offices.

Our readings became common reference points during our conversations and also helped us begin a collaborative writing effort. We began to look critically at the artifacts we had collected during the previous two years. Reading transcripts of our conversations through Grant and Agosto's (2008) lens of social justice as a goal, 
process and stance, for example, we were able to examine the path our group took and to reflect on its impact on the individual members.

We recognized that our professional development efforts were recursive rather than linear in nature and that our recursive process had affected us as researchers and teachers. The multifaceted approach to self-directed professional development (Diaz-Maggioli, 2004) served us well. Our efforts fell into four areas: the discussions of shared readings; conversations about our individual experiences as higher educators and researchers; sharing and discussion of individual reflective writing pieces related to social justice; and collaboration on scholarly writing endeavors.

\section{The Impact of Our Self-Study Group}

In the dialogic space (Nystrand, 1982) that emerged during our data analysis discussions, we became increasingly cognizant of the impact of our discussions. We began to notice three results of our work together: (1) an expansion and deepening of our understandings of social justice, (2) a critical analysis of our own teaching that resulted in more overt teaching for social justice, and (3) a developing collaborative problem-solving community. We discuss each of these impacts in further detail below.

\section{Expanding Our Understandings of Social Justice}

By developing a learning community where we shared ideas, discussed and questioned perspectives, and circulated knowledge, each of us expanded our understandings of social justice. There were significant shifts in the ways that we individually conceptualized social justice: from vague, "bookish" jargon to language that represented a developing understanding of social justice as praxis. For example, discussions about the differences between multiculturalism and social justice helped each of us to make our language use more explicit. As a group we determined that social justice involved more than just a cerebral understanding of inequality and injustice. Each group member achieved some level of transformation by developing the language, knowledge, and understandings associated with social justice. Most importantly, we were able to transfer our understanding of social justice into expectations that our students would demonstrate social justice as a goal, a process, and a stance (Grant \& Agosto, 2008).

\section{Analyzing Our Own Teaching}

The experiences of participating in discussions on social justice prompted members to rethink their teacher preparation coursework. Over the first two years of conversations, we examined student work; we revisited the assignments and readings that were integral parts of our coursework; we made the decision to teach more overtly for social justice.

The first step we took in our goal to be more overt in our teaching came in the form of a group project. Members of our inquiry team conceptualized, designed, and implemented a two-week summer institute that focused on social justice. During that institute, we were able to assess specifically students' understanding of the construct. We affirmed that focusing overtly on issues of social justice is necessary for students to grapple with them and to incorporate teaching for social justice into their practice.

To this end, group members altered syllabi, adding texts on educational equity, culturally responsive teaching, and critical pedagogy; specifically, writings by Sonia Nieto, Paolo Freire, Shirley Brice-Heath, and James Banks were added to 
required course readings. We each also revisited and modified course assignments. For example, in the first year of meetings, Molly expressed concern that a required course assignment in which students create a literacy-rich thematic unit did not integrate elements of social justice. Through conversations, she re-envisioned the assignment and added a component in which students reflect on their actions and instructional choices as culturally relevant teachers.

\section{Creating a Problem-Solving Community}

As the group developed, we began regularly engaging in problem solving, and this reflection and collaboration continues to be a priority. We believe that we accomplished much of our growth through collaborative problem solving and critical reflection as a community of learners. Aida, for example, shared a story about a student who challenged her notions of critical literacy, and in discussing her response to the student with the group, she felt validated in her actions. The scheduled meetings of the research group provided a regular opportunity for us to discuss these types of problems and to reflect on our teaching, and they opened the door to significant informal conversations. For example, Kristen rushed to Jane's classroom after dialoguing with a student who was dealing with racial tensions in his school and who had asked her to offer advice to him and his colleagues to fix the problem. Worried about her response to the student, Kristen relayed the conversation to Jane, who not only reassured her but also agreed to speak to the student herself.

We regularly found ourselves informally reaching out to other members of the group in order to reflect on issues related to our teaching, interactions with students, and even situations with other colleagues. This aspect of the learning community has been an essential vehicle by which we arrived at increased theoretical and pedagogical understandings. In striving to understand issues of social justice together, we uncovered a valuable resource in the group as a whole. As a result, we are no longer individual faculty members who work in isolation; we are part of a community of learners "who are differently positioned from one another and who bring different kinds of knowledge and experience to bear on the collective enterprise" (Cochran-Smith et. al, 1999, p. 233).

\section{Where We Plan to Go From Here}

Though our collaborative efforts have resulted in deepened understandings of social justice and its impact on our professional lives, our work in teaching for social justice has only begun. Theoretical understanding and pedagogical change are certainly two desirable outcomes of any professional development endeavor of educators. We have become more overt, but we need to assess the effect our transformation is having. We want to know whether our students are parroting our own beliefs or whether they will work to achieve social justice as a goal, process, and stance with their own students. Will they become the agents of change that we hope they will be? This question remains for our inquiry group to tackle.

Cochran-Smith (2004) explains that working for social justice in education means guiding students in critical inquiry of the dynamics of oppression and privilege and challenging preexisting hierarchies. Specifically, we want to examine students' work in our courses and in their field experiences to evaluate the impact of our practices. Ultimately, we want to uncover how our actions impact the lives of students in elementary and secondary schools where our students teach. In addition, having experienced the benefits of collaboration, we want to encourage our students to work collaboratively, to develop professional communities where they can learn from each other as we have. 
Three of the members of the group work together in the adolescence education program. As we continue to move forward we will use our findings from this group to shape the redesign of our initial teacher education programeverything from assessments to field experiences to the literature our students read.

Finally, we hope to open up our conversations to additional members both within the school of education and the larger university. Several new members have joined us at various points in the last three years; our objectives are to continue to invite and welcome new colleagues into our conversations in more comprehensive ways. It is our belief that new participants will enter into a mutually beneficial endeavor; they will likely benefit from undergoing the transformations we have explained throughout this article and we will certainly benefit from new perspectives. We are particularly interested in having group membership become even more heterogeneous in order to have meaningful conversations about the connections between race, ethnicity, gender, language, religion, and sexual orientation and social justice.

\section{Advice to Those Interested in Following Similar Directions}

As we have come to understand the benefits of our work together, we encourage our higher education colleagues to explore similar projects. We believe that our model is replicable and offer the following suggestions for interested parties. We formed our group on a voluntary basis and allowed our own interests to determine the agenda and direction. All division faculty members were invited to attend, regardless of experience, rank, or specialization; as a result, our group comprised both junior and tenured faculty, novices and veterans, and a wide range of teaching and research expertise. This diverse membership was advantageous in our learning; however, it is essential to create a safe environment which encourages multiple perspectives and honors and respects diverse experiences and viewpoints.

We found it helpful to have a group coordinator who was responsible for planning our meetings, facilitating conversations, and reminding us of our long-term goals. Though our group membership was relatively fluid, as members came and went for professional and personal reasons, it was also essential for us to maintain a core of members who were

\section{It is essential to create a safe environment which encourages multiple perspectives and honors and respects diverse experiences and viewpoints.} consistent over the years. Our group members also committed to regular conversations; through our monthly meetings, we set reasonable goals for our learning and self-monitored our progress. We would also recommend a multifaceted approach of writing, reading, and conversing; it was the combination of all three processes that expanded our thinking and added to our knowledge bases.

To encourage similar cross-curricular collaborations, universities must embrace faculty efforts. We were fortunate that our work together was valued by our university administration; we were publically commended at faculty meetings by our division chair and our dean. Several members of the group came into the group thinking there would be a reward such as support in producing publications or progress in the processes of promotion, tenure, and merit. When the opportunities arose, we noted our participation in the group on applications for reappointment and merit. In addition, throughout the three years, we devoted time to giving feedback and advice to individuals working on research and writing. In the end, however, group members must value both the process of these collaborative experiences as well as the product of articles, chapters, and presentations that may emerge as a result of the process. 


\section{Concluding Thoughts}

In sum, our efforts to create a self-directed professional development group of higher educators proved to be highly valuable for us. Not only did we expand our own knowledge and understandings of notions of social justice, but we began to take important steps towards increasing our social justice actions in our teaching. As Sensoy and DiAngelo (2009) explain, “just agreeing that social justice is important is not enough. Educators must practice social justice or else the concept is meaningless" (p. 345). Over a three-year period, we found meaning in the concept of social justice. Our conceptual understandings became practical agendas. Through this collaborative process, we grew as individuals who are committed to issues of equality, we grew as higher educators for social justice, and perhaps most importantly we grew as a community of teachers and learners.

\section{References}

Anagnostopolous, D., Smith, E.R.., \& Nystrand, M. (2008). Creating dialogic spaces to support teachers' discussion practices: An introduction. English Education, 41, 4-12.

Birchak, B., Connor, C., Crawford, K., Kahn, L., Kaser, S., Turner, S., \& Short, K. (1998). Teacher study groups: Building community through dialogue and reflection. Urbana, IL: NCTE.

Brancato, V.C. (2003). Professional development in higher education. New Directions for Adult and Continuing Education, 98, 59-65.

Brookfield, S. D. (1987). Developing critical thinkers. San Francisco: Jossey-Bass.

Cazden, C. (2001). Classroom discourse: The language of teaching and learning. Portsmouth, $\mathrm{NH}$ : Heinemann.

Chandler-Olcott, K. (2002). Journey into the wilderness: A teacherresearcher group's retreat. In S. Intrator (Ed.), Stories of the courage to teach: Honoring the teacher's heart (pp. 218-229). San Francisco: Jossey-Bass.
Cochran-Smith, M., Albert, L., Dimattia, P., Freedman, S., Jackson, R., Mooney, J., Neisler, O., Peck, A. \& Zollers, N. (1999). Seeking social justice: A teacher education faculty's self-study. International Journal of Leadership in Education, 2 (3), 229253.

Cochran-Smith, M., \& Lytle, S.L. (1999). Relationship of knowledge and practice: Teacher learning in communities. Review of Research in Education, 24, 249-305.

Cochran-Smith, M. \& Lytle, S.L. (2001). Beyond certainty: Taking an inquiry stance on practice. In A. Lieberman \& L. Miller (Eds.), Teachers caught in the action: Professional development that matters (pp. 45-60). New York: Teachers College Press.

Cochran-Smith, M. (2004). Walking the road: Race, diversity, and social justice in teacher education. New York: Teachers College Press.

Díaz-Maggioli, G. (2004). Teachercentered professional development. Alexandria, VA: Association for Supervision and Curriculum Development. 
El-Haj (2004). Constructing ideas about equity from the standpoint of the particular: Exploring the work of one urban teacher network.

Teacher's College Record, 105, 817845

Fecho, B. (2000). Developing critical mass: Teacher education and critical inquiry pedagogy. Journal of Teacher Education, 51(3), 194-199.

Fecho, B., \& Allen, J. (2002). Teachers researching communities of practice for social justice. School Field, XII (3/4), 119-141.

Gallavan, N. (2000). Multicultural education at the academy: Higher educators' challenges, conflicts, and coping skills. Equity \& Excellence in Education, 33, 5-11.

George, M. (2004). Faculty-student book clubs create communities of readers in two urban middle schools. Middle School Journal, 35(3), 21-26.

Grant, C., \& Agosto, V. (2008). Teacher capacity and social justice in teacher education. In M. CochranSmith, S. Feinman-Nemser, J. Mcl ntyre, \& K. Demers (Eds.), Handbook of research on teacher education: Enduring questions in changing contexts. Mahwah, N.J.: Lawrence Erlbaum Publishers.

Grossman, P., Wineburg, S., \& Woolworth, S. (2001). Toward a theory of teacher community. The Teachers College Record, 103, 9421012.
Lewis, C., \& Ketter, J. (2004). Learning as social interaction: Interdiscursivity in a teacher and researcher study group. In R. Rogers (Ed.), An introduction to critical discourse analysis in education (pp. 117-146). Mahwah, NJ: Lawrence Erlbaum Associates.

Little, J. W. (1990). Teachers as colleagues. In A. Lieberman (Ed.), Schools as collaborative cultures: Creating future now (pp. 165-193). Bristol, PA: The Falmer Press.

Lortie, D. (1975). Schoolteacher: A sociological study. Chicago: University of Chicago Press.

Lyons, C.A., \& Pinnell, G.S. (2001). Systems for change in literacy education: A guide to professional development. Portsmouth, $\mathrm{NH}$ : Heinemann.

Mezirow, J. (Ed.). (2000). Learning as transformation: Critical perspectives on a theory in progress. San Francisco: J ossey-Bass.

Moon, J. (1999) Reflection in learning and professional development:

Theory and practice. London: Kogan.

Nystrand, M. (1982). The structure of textual space. In M. Nystrand (Ed.), What writers know: The language, process, and structure of written discourse (pp. 75-86). New York: Academic Press.

Pratt, D. (1998). The research lens: A general model of teaching. In D. Pratt \& Associates (Eds.), Five perspectives on teaching in adult and higher education ( pp. 3- 14). Florida: Kreiger Publishing Company.

Richlin, L., \& Essington, A. (2004).

Overview of faculty learning 
communities. New Directions for Teaching \& Learning, 97, 25-39.

Richlin, L., \& Cox, M. D. (2004). Developing scholarly teaching and the scholarship of teaching and learning through faculty learning communities. New Directions for Teaching \& Learning, 97, 127-135.

Rogers, R., Kramer, M.A., Mosley, M., Fuller, C., Light, R., Nehart, M., et al. (2005). Professional development as social transformation: The literacy for social justice teacher research group. Language Arts, 82, 347-358.

Sandretto, S., Ballard, K., Burke, P., Kane, R., Lang, C., Schon, P., et al. (2007). Nailing jello to the wall: Articulating conceptualizations of social justice. Teachers and Teaching: Theory and Practice, 13(3), 309-324.
Schön, D. A. (1997). Educating the reflective practitioner: Toward a new design for teaching and learning in the professions. San Francisco, CA: Jossey-Bass.

Sensoy, O., \& DiAngelo, R. (2009). Developing social justice literacy: An open letter to our faculty colleagues. Phi Delta Kappan, 90(5), 345-353.

Smith, K. (2003). So, what about the professional development of higher educators. European Journal of Teacher Education, 26(2), 201-215.

West, W. (1996). Group learning in the workplace. New Directions for Adult and Continuing Education. 71,51-60.

Wlodkowski (1999). Enhancing adult motivation to learn: A comprehensive guide for teaching all adults. San Francisco: Jossey-Bass.

Molly Ness is an assistant professor in childhood education at Fordham University in New York City. Marshall George is an associate professor in English education at Fordham University. Kristen Turner is an assistant professor in English education at Fordham University. Jane Bolgatz is an associate professor in social studies education at Fordham University. 


\section{Appendix A}

A Sampling of the Readings We Completed Over Our Three-Year Effort

Bolgatz, J. (2005). Revolutionary talk: Elementary teacher and students discuss race in a social studies class. The Social Studies, 96(6), 259-264.

Bolgatz, J. (2005). Talking race in the classroom. New York: Teachers College Press.

Cazden, C. (2001). Classroom discourse: The language of teaching and learning. Portsmouth, $\mathrm{NH}$ : Heinemann.

Cornbleth, C. (2008).Diversity and the new teacher: Learning From experience in urban schools. New York: Teachers College Press.

Christensen, L. (2001). Reading, writing, and rising up: Teaching about social justice and the power of the written word. Milwaukee, WI: Rethinking Schools.

Fine, M., Weis, L., Powell, L. \& Wong, M. (1997). Off white: Readings on race, power, and society. New York: Routledge.

Grant, C., \& Cooper, J. (2002). An educator's guide to diversity in the classroom. Boston: Houghton Mifflin.

Grant, C., \& Agosto, V. (2008). Teacher capacity and social justice in teacher education. In M. Cochran-Smith, S. Feinman-Nemser, J. Mcl ntyre, \& K. Demers (Eds.), Handbook of research on teacher education: Enduring questions in changing contexts. Mahwah, N.J.: Lawrence Erlbaum Publishers.

Greene, S. \& Abt-Perkins, D. (2003). Making race visible: Literacy research for cultural understanding. New York: Teachers College Press.

Heffernan, L. (2004). Critical literacy and the writer's workshop: Bringing purpose and passion to student writing. Newark, DE: International Reading Association.

Ladson-Billings, G. (2001). Crossing over to Canaan: The journey of new teachers in diverse classrooms. New York: Jossey-Bass.

Landsman, J., \& Lewis, C. (2006). White teachers / diverse classrooms: A guide to building inclusive schools, promoting high expectations, and eliminating racism. Sterling, VA: Stylus.

Lewis, C. (2000). Limits of identification: The personal, pleasurable, and critical in reader response. Journal of Literacy Research, 32(2), 253-266.

Lewis, C. (2006). Reframing sociocultural research on literacy: Identity, agency, and power. London: Lawrence Erlbaum Associates.

Nieto, S. (2004). Affirming diversity: The sociopolitical context of multicultural education. New York: Longman.

Nieto, S. (2002). Profoundly multicultural questions. Educational Leadership, 60(4), 6-10.

Sensoy, O. \& DiAngelo, R. (2009). Developing social justice literacy: An open letter to our faculty colleagues. Phi Delta Kappan, 90(5), 345-353.

Vasquez, V. (2003). Getting beyond 'I like the book': Creating space for critical literacy in K-6 Classrooms. Newark, DE: International Reading Association. 


\section{Appendix B}

Linguistic Dimensions Study

There is much more to language and literacy than reading the great works and writing a good essay. However, these skills are often what is valued in school. In this project, you will explore the ways that students use linguistics, language, and literacies in and out of school. You will work to find ways to bridge the gap between the "local literacies" of the students' home community and the academic literacies valued in school. This study will require traditional methods of research (library, journals, etc.) and methods of "teacher-research" that we will discuss in class.

\section{Phase 1: Community Selection}

Select a community that represents the student population within your school or within a school where you would like to teach. You may choose to select two or three focal students from your classes to serve as case studies for this community. Write a one-paragraph description of the community (the primary discourse) and of the students who represent that community. List your potential data sources for uncovering information about the students' use of language, linguistics, and literacies in and out of school. Post this information on your personal wiki page.

\section{Phase 2: Data Collection}

Collect data on the uses of literacy within the selected community. Examine linguistic practices (including how words sound and what they mean) and social practices. Potential sources of inquiry include:

\begin{tabular}{|l|l|}
\hline $\begin{array}{l}\text { Overheard conversations } \\
\text { (perhaps recorded) }\end{array}$ & $\begin{array}{l}\text { Running records of your } \\
\text { observations (what } \\
\text { you hear and what you see) }\end{array}$ \\
\hline Writing & $\begin{array}{l}\text { Student interviews (and other } \\
\text { interviews) }\end{array}$ \\
\hline Other artifacts & Library/Internet research \\
\hline Photos & Radio/TV/Media \\
\hline
\end{tabular}

Bring the data you have collected to class so that you can begin to analyze what you have found. Post a list of the sources of your data on your wiki page.

\section{Phase 3: Analysis and Findings}

In class you will share your data with your analysis team, which will help you to begin to:

- $\quad$ Categorize the local literacies

- Examine the diversity and ways of meaning in the community

- Articulate the home literacies of the students Continue this analysis after this class session and identify three to four key findings. You should document the finding and provide supporting evidence from the data you have collected. Post these findings to your personal wiki page.

\section{Phase 4: Turn to Teaching}

Consider the language and literacy practices of the community you have studied, and think about how this knowledge could influence your practice as a teacher of students from this community. What theories and strategies would support the academic success of the students? Reference course texts and other sources you consult as you make a plan for teaching members of this community. Use teacher-research skills to connect your work with the ideas of researchers and theorists we have studied. The report should be in APA format. 


\section{Appendix C}

Social Studies Curriculum: Cultural/Political Event

For this assignment you will go to a political or cultural event that is not something you would ordinarily attend. This might be a religious service, a political meeting, an MTA open meeting about transit changes, a Young Republicans meeting, a cultural celebration. The idea is that you are getting out and learning something NEW in an active, participatory way. Choose an event that you would not go to otherwise. Take a leap or risk of some sort (i.e. see a group you suspect you will disagree with; an event in a neighborhood where you do not normally feel comfortable exploring, etc.).

\section{BE SURE TO GET NECESSARY I NVITATIONS AND DRESS APPROPRIATELY.}

You will then write a response answering the following questions in as creative a way as you like ( 1 page):

What did you see and do? What did you learn from the event? How does this relate to social studies? How does this relate to the readings and conversations in our class? Reference NCSS or NYState standards. If students went to this event, what would they learn? What questions would this spark? What would students need to know to best appreciate the event?

\section{Appendix D}

Assignments Jane added to her curriculum course

\section{8: Map of school}

Using the questions generated in the first class, you will create a map of your school and surrounding neighborhood noting significant cultural, economic, social, and political places.

\section{9: Community Analysis Sheet}

\begin{tabular}{|l|l|l|}
\hline $\begin{array}{l}\text { An excellent teacher in } \\
\text { your school }\end{array}$ & $\begin{array}{l}\text { Description/ Explanation } \\
\text { effective? Be specific. If } \\
\text { possible, relate to criteria } \\
\text { described in Ladson-Billings* } \\
\text { or other theory. }\end{array}$ & $\begin{array}{l}\text { How this resource/issue might be used } \\
\text { him/her to plan or talk about teaching? Interview } \\
\text { students to see why they think he/she is } \\
\text { effective? Team-teach with the teacher? }\end{array}$ \\
\hline $\begin{array}{l}\text { A community-based } \\
\text { organization housed in or } \\
\text { associated with your } \\
\text { school }\end{array}$ & $\begin{array}{l}\text { How does this organization } \\
\text { work with students? In what } \\
\text { ways is it utilized? What } \\
\text { makes it effective? }\end{array}$ & $\begin{array}{l}\text { How might you partner with this organization? } \\
\text { What can you learn from this organization? Could } \\
\text { it be improved in some way? }\end{array}$ \\
\hline $\begin{array}{l}\text { A resource in the local } \\
\text { community, such as a } \\
\text { community center, } \\
\text { mosque, church, or } \\
\text { synagogue }\end{array}$ & $\begin{array}{l}\text { How does this organization } \\
\text { work with students? In what } \\
\text { ways is it utilized? What } \\
\text { makes it effective? }\end{array}$ & $\begin{array}{l}\text { How might you partner with this organization? } \\
\text { What can you learn from this organization? Could } \\
\text { it be improved in some way? }\end{array}$ \\
\hline $\begin{array}{l}\text { A compelling social, } \\
\text { economic or political } \\
\text { issue in the local } \\
\text { community such as high } \\
\text { asthma rates, high }\end{array}$ & $\begin{array}{l}\text { What are the history and } \\
\text { politics of this issue? How } \\
\text { does it affect the people in the } \\
\text { community? }\end{array}$ & $\begin{array}{l}\text { How might some of the issues students are } \\
\text { learning about in your class be related to this } \\
\text { issue? In what ways are the } \\
\text { political/social/economic questions or aspects of } \\
\text { the issue similar to what students are learning } \\
\text { about in history? How might you craft an } \\
\text { essential question that would relate to both this } \\
\text { issue and the other content of your class? }\end{array}$ \\
\hline
\end{tabular}

*Ladson-Billings, G. (2006). "Yes, but how do we do it?" Practicing culturally relevant pedagogy. White teachers/diverse classrooms: A guide to building inclusive schools, promoting high expectations, and eliminating racism. J. Landsman and $\mathrm{C}$. Lewis (Eds.). Sterling, VA, Stylus. 